University of Nebraska - Lincoln

DigitalCommons@University of Nebraska - Lincoln

\title{
$5-2009$
}

\section{Avian Foraging Patterns in Crop Field Edges Adjacent to Woody Habitat}

Heidi L. Puckett

University of Nebraska-Lincoln

James R. Brandle

University of Nebraska - Lincoln, jbrandle1@unl.edu

Ron J. Johnson

University of Nebraska-Lincoln, ronj@clemson.edu

Erin E. Blankenship

University of Nebraska-Lincoln, erin.blankenship@unl.edu

Follow this and additional works at: https://digitalcommons.unl.edu/natrespapers

Part of the Natural Resources and Conservation Commons

Puckett, Heidi L.; Brandle, James R.; Johnson, Ron J.; and Blankenship, Erin E., "Avian Foraging Patterns in Crop Field Edges Adjacent to Woody Habitat" (2009). Papers in Natural Resources. 160.

https://digitalcommons.unl.edu/natrespapers/160

This Article is brought to you for free and open access by the Natural Resources, School of at DigitalCommons@University of Nebraska - Lincoln. It has been accepted for inclusion in Papers in Natural Resources by an authorized administrator of DigitalCommons@University of Nebraska - Lincoln. 
Published in Agriculture, Ecosystems \& Environment 131:1-2 (May 2009), pp. 9-15; doi 10.1016/j.agee.2008.08.015; Special Issue - Temperate agroforestry: When trees and crops get together. Copyright @ 2008 Elsevier B.V. Used by permission. http://www.elsevier.com/locate/agee

Submitted February 22, 2008; revised August 28, 2008; accepted August 29, 2008; published online October 17, 2008.

\title{
Avian foraging patterns in crop field edges adjacent to woody habitat
}

\author{
Heidi L. Puckett, ${ }^{1}$ James R. Brandle, ${ }^{1}$ Ron J. Johnson,,${ }^{1,3}$ and Erin E. Blankenship ${ }^{2}$ \\ ${ }^{1}$ School of Natural Resources, University of Nebraska-Lincoln, Lincoln, NE 68583, USA \\ ${ }^{2}$ Department of Statistics, University of Nebraska-Lincoln, Lincoln, NE 68583, USA \\ ${ }^{3}$ Current address: Department of Forestry and Natural Resources, Clemson University, Clemson, SC 29634, USA. \\ Corresponding author-H. L. Puckett; current address: Department of Wildlife and Fisheries, Mississippi State University, \\ Mississippi State, MS 39762, USA; tel 662 325-2384, fax 662 325-8726, email hpuckett@cfr.msstate.edu
}

\begin{abstract}
As natural predators of pest insects, woodland birds provide biological pest suppression in crop fields adjacent to woody edges. Although many birds using these habitats forage widely, earlier studies have found that most foraging activity occurs within $50 \mathrm{~m}$ of the woody edge. The goals of this study were to determine the primary area of use, or functional edge, for birds foraging in crop fields adjacent to woody edges, and to evaluate their foraging distance patterns. During the summers of 2005 and 2006, avian foraging behavior was observed at 12 research sites in east central Nebraska that contained either a shelterbelt or woody riparian edge. At each site, perches were provided at $10 \mathrm{~m}$ intervals out from the edge and insect larvae were placed in feeders at random locations to simulate a pest insect food resource. Birds were recorded foraging in five distance categories out from the edge $(0-10,10-20,20-30,30-40$, and 40-50 m). Seven species foraged primarily within $20 \mathrm{~m}$ of the edge (72\% all observations; 79\% without perch or feeder observations). Ten species foraged throughout the plots but six of these generally foraged more often (45\% and $49 \%)$ and four less often $(30 \%$ and $30 \%)$ within $20 \mathrm{~m}$ of the edge. The 13 species that tended to forage more often within $20 \mathrm{~m}$ of the edge, with $56 \%$ of their foraging overall in this area, also tended to forage farther when perch and feeder observations were included, indicating willingness to forage farther when food resources were available. Based on a repeated measures analysis of variance, foraging distances appeared to be greater at sites with soybean as the planted crop, although this apparent trend was significant for only some species. There was no clear difference in foraging distances outward from shelterbelt versus riparian sites. These results indicate that conservation efforts within the $20 \mathrm{~m}$ functional edge offer potential to enhance the sustainability of both birds and crops in agricultural
\end{abstract}

\section{Introduction}

Woody habitats in agroecosystems provide economic benefits to agriculture by serving as protective barriers from strong winds, thus increasing crop yields, reducing wind erosion, and improving soil moisture conservation (Brandle et al., 2004). These habitats also contribute to diverse landscapes that benefit vertebrate and invertebrate diversity in agroecosystems (Johnson and Beck, 1988; Benton et al., 2002; Perkins et al., 2003) and the biological suppression of crop pests (Johnson et al., 1992; Kirk et al., 1996; Tremblay et al., 2001; Bianchi et al., 2006; Tsitsilas et al., 2006). They provide protection from harsh weather, escape cover from predators, food and foraging sites, reproductive habitat, and travel corridors (Johnson and Beck, 1988). Although various habitat types in agroecosystems contribute uniquely to habitat needs of various species, including woodland and grass- land birds (Best et al., 1995; Henningsen and Best, 2005), woody habitats support the highest avian species richness in agricultural areas (Best et al., 1995; Jones et al., 2005) and are often the only habitats suitable for local species in intensively farmed areas.

Along with other natural predators of pest insects, birds contribute to a reduction of pest insect populations in crop fields adjacent to non-crop habitats (Johnson et al., 1992; Kirk et al., 1996; Tremblay et al., 2001; Jones et al., 2005). Though many birds have been known to feed $200 \mathrm{~m}$ or more from the crop field edge, they typically concentrate foraging efforts within $50 \mathrm{~m}$ of the edge because of the proximity of protective cover (Best et al., 1990; Fitzmaurice, 1995; Sunderman, 1995).

Some agricultural fields offer more potential food resources for birds than do others (Christensen et al., 1996; Beecher et al., 2002). Our study used perches, feeders, and observations of birds 
near edges to examine distances that birds travel out from woody edges to obtain food resources. Our purpose was to determine which avian species most actively forage in crop fields adjacent to woody edges and where, within the $50 \mathrm{~m}$ edge, they prefer to forage. Foraging distance patterns out from woody edges were evaluated to determine whether they varied with site-specific characteristics (type of woody edge, planted crop). With this information, it might be possible to develop management practices directed toward functional edges, where most avian foraging activity occurs, allowing producers to optimize their use of avian predators while maintaining profitable crop production systems.

\section{Methods}

\subsection{Study areas}

This study was conducted at research sites in a $100 \mathrm{~km}^{2}$ area in east central Nebraska during the summers of 2005 and 2006. Landscape-scale effects on birds through this area were expected to be similar because landscape cover was fairly uniform. Sixtyeight percent of the land in the study area was in row crops or small grains, $27 \%$ in grass or alfalfa, $2 \%$ in woody areas, and $3 \%$ in other land-use categories (roads, water, wetlands, towns, etc.). There were 10 research sites in 2005. In 2006, two additional sites were added, for a total of 12 sites. Sites consisted of a linear woody edge (either a woody riparian edge or shelterbelt) with an adjacent agricultural crop field planted to either corn (Zea mays L.) or soybean (Glycine max L. Merr.). In 2005, six sites were planted to corn and four to soybean. In 2006, five were planted to corn and seven to soybean. Sites were divided into pairs with one shelterbelt and one woody riparian edge per pair, for a total of five pairs in 2005 and six in 2006. Predominant woody species in shelterbelts were red mulberry (Morus rubra L.), eastern redcedar (Juniperus virginiana L.), hackberry (Celtis occidentalis L.), American elm (Ulmus americana L.), and honeylocust (Gleditsia triacanthos L.). Predominant woody species in woody riparian edges were green ash (Fraxinus pennsylvanica L.), red mulberry, Russian olive (Elaegnus angustifolia L.), Siberian elm (Ulmus pumila L.), American elm, and honeylocust. Average width of the shelterbelts in the study was $15 \mathrm{~m}$; average length, $537 \mathrm{~m}$; and typical height, 15-20 m. Average width of the riparian systems was $35 \mathrm{~m}$; average length, $1000 \mathrm{~m}$; and typical tree heights, 20$30 \mathrm{~m}$. Sites were paired based on proximity to minimize travel time between sites. The planted crop and woody species in the edges were not factors in determining site pairs.

At each site, a $100 \mathrm{~m} \times 50 \mathrm{~m}$ study plot was created in the crop field adjacent to the woody edge and at least $50 \mathrm{~m}$ away from any other wooded area (Figure 1 ). Within each plot, five $100 \mathrm{~m} \times 10 \mathrm{~m}$ subplots were created to represent distance categories out from the edge $(0-10,10-20,20-30,30-40$, and 40$50 \mathrm{~m}$ ). A feeder was placed randomly within each of these subplots for a total of five feeders per site. Feeders were $30 \mathrm{~cm}$ in diameter, $5 \mathrm{~cm}$ deep, and adjustable in height so they were visible above the crop canopy throughout the research season. Approximately 200 mealworms (Tenebrio molitor L.) were placed in three randomly selected feeders and were identified as active feeders. To be sure birds did not automatically associate feeders with a food source, the two remaining feeders contained no mealworms and were inactive. Feeders were moved to new randomly selected locations within each subplot and activity status was randomly re-assigned about every 13-14 days during 2005 and every 6-7 days in 2006 to simulate potential pest outbreaks in the crop field. Feeders were filled just before observations began the next morning and on subsequent mornings until they were moved to a new location.

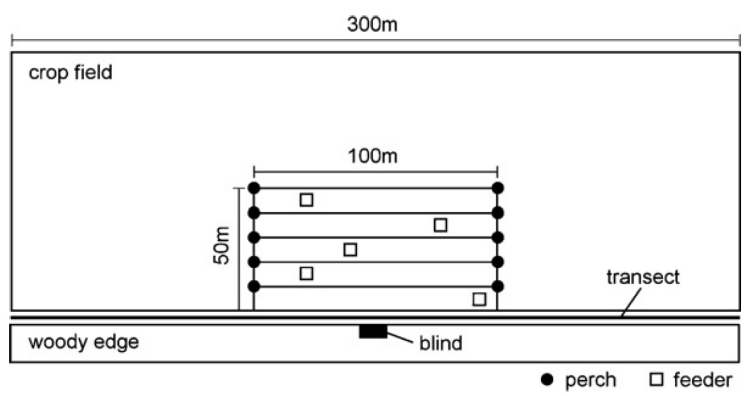

Figure 1. Plot design used at research sites showing perch locations and an example of random feeder arrangement at 12 research sites in east central Nebraska.

At each site, 1.5-m tall perches were erected to accommodate foragers such as the Eastern Kingbird (Tyrannus tyrannus) that often capture insects in midair by flying from perches. Five perches were placed along each side of the plot at $10 \mathrm{~m}$ intervals for a total of ten perches per site. These perches would show distances from the edge where birds perch when options are available, and were expected to clarify where bird-friendly management practices (e.g., reduced pesticide use or specifically placed tall forbs or artificial perches) might be evaluated as management options. Perches remained in soybean fields throughout both research seasons. Perches in corn fields were removed the second week in July in both seasons because the crop canopy exceeded the height of the perches. Because feeders and perches were artificial additions to the crop fields, foraging patterns were compared with and without observations on the feeders and perches to detect potential effects they had on foraging patterns.

\subsection{Avian surveys}

Bird observations were conducted from sunrise to $4 \mathrm{~h}$ later (Robbins, 1981). Sites were observed for 30-min periods with observations recorded in 15, 2-min intervals. The order site pairs were observed was randomized. The species of birds observed within the study plots were recorded, along with their arrival and departure direction and time, and foraging distance(s) into the crop field from $0 \mathrm{~m}$ at the field edge. Feeders and perches the birds visited while in the crop field were also recorded.

Each site was observed at least nine times between May 23 and July 2, 2005. Only soybean fields were observed between July 12 and August 10, 2005, because the crop height in corn fields reduced bird detectability. In 2006, all site pairs were observed 10-14 times between May 10 and July 20. Observation stands approximately $3 \mathrm{~m}$ high were used at sites with corn as the planted crop during the 2006 research season to maintain visual contact of the study plots.

In 2006, a 30-min, 300-m (270 $\mathrm{m}$ at one site) transect survey was conducted at the first site observed each day to determine species present at the sites and to compare with species observed in study plots. The transect line was along the woody edge and adjacent crop field and extended $100 \mathrm{~m}$ on either side of the $100 \mathrm{~m} \times 50 \mathrm{~m}$ plot. Transect surveys at all sites were done at a traveling speed of $10 \mathrm{~m} / \mathrm{min}$. All bird species seen or heard within the woody edge or adjacent crop field during the survey were recorded.

\subsection{Data analysis}

Sorenson's similarity index was used to measure the similarity in species composition at woody riparian edges and shelterbelts using data collected during the transect surveys in 2006 
(Sorensen, 1948). Sorenson's similarity index, $S$, is calculated as:

$$
S=(2 \times K) \div(A+B)
$$

where $A$ is the number of species observed in woody riparian edges, $B$ is the number of species observed in shelterbelts, and $K$ was the number of species observed in both types of woody edge.

The number of 2-min intervals during which birds were observed on the ground, on perches, and at active and inactive feeders was recorded for each distance category (0-10, 10-20, $20-30,30-40$, and $40-50 \mathrm{~m}$ ). To obtain a measure of total use within each distance category, all 2-min intervals in which a bird was present were recorded. That is, if a bird entered a distance category and foraged there for more than one 2-min interval, the additional intervals were included as observations (observation by distance $\times$ total 2 -min intervals present). To determine distances species chose to travel into a crop field, each new bird entry into a distance category was used as one observation at that distance, regardless of how long the bird remained there. These two approaches provide a relative measure of total use or time spent foraging at each distance category (using total 2-min intervals) and a measure of distance from the edge birds selected each time they entered a distance category (using each new bird entry).

Total-use observations (total intervals) were used to develop bar graphs to illustrate foraging patterns by species out from the field edge. Observations were separated by active feeder, inactive feeder, perch, and ground to differentiate avian use of artificial and natural components in the crop field. Because the number of observation periods for active feeders varied by distance category from 86 to 118 , active feeder observations were unequal across distance categories. To account for this so that all five distance categories were represented equally, we present results as bird observations per 100 observation periods and use only sites where the species was observed during the season. We use the same approach for ground and perch data. The resulting bar graphs represent the number of birds observed per 100 observation periods, by species and distance, for ground, perch, active feeders, and inactive feeders, across sites where a species was observed. In considering results for the five distance categories, we would expect $20 \%$ of foraging observations in each category if all distances were used equally. Observations of birds foraging more than $20 \%$ in any distance category could indicate preference for that distance, whereas observations below $20 \%$ could indicate less use or avoidance. We evaluated these bar graph patterns, by species, using Chisquare goodness-of-fit tests to determine whether each species used all distance categories equally, and to compare expected use in the first two distance categories (within $20 \mathrm{~m}$ ) to that in the farther categories (beyond $20 \mathrm{~m}$ ).

Foraging distances of species with $\geq 30$ observations (using observations of each new bird entry) were analyzed using a repeated measures analysis of variance, implemented in SAS PROC MIXED (SAS Institute Inc., 2000-2004), with the week of the breeding season as the repeated measure. All potential interactions between the type of woody edge (woody riparian edge or shelterbelt), crop type (corn or soybean), and week, were evaluated. Average foraging distances for observed species were calculated based on site, site pair, and crop. Foraging distances associated with type of woody edge and crop were evaluated for each species. Least square means were calculated for these factors to determine differences in travel distances based on type of crop or woody edge, using $a=0.05$.

\section{Results}

Thirty bird species were observed foraging within the study plots, with four of these species observed only in 2005, 11 only in 2006, and 15 observed both years. During 2006, 46 species were observed in the transect surveys, with six observed only at shelterbelt sites, 13 only at riparian sites, and 27 at both. Sorenson's similarity index determined that woody riparian edges and shelterbelts were $74 \%$ similar in avian species composition.

Arrival and departure directions for birds foraging in the crop fields indicated that a majority of the birds traveled directly to and from the woody edge at all sites. At shelterbelt sites, $58 \%$ of the birds traveled from the woody edge into the crop field and 56\% returned to the edge. Percentages were higher at riparian sites, with $82 \%$ coming from the edge and $71 \%$ returning to it.

Seventeen species had sufficient observations recorded in 2min intervals (16-274; Table 1) to evaluate their foraging patterns individually. Of these 17 species, seven foraged primarily within $20 \mathrm{~m}$ of the edge $\left(x^{2} \geq 8.79\right.$, d.f. $\left.=1, P \leq 0.003\right)$, with $72 \%$ of their foraging activity occurring within this area when feeder and perch observations were included, and $79 \%$ when not included (Table 1; Figure 2). Ten species foraged throughout the plots but six of these generally foraged more often within $20 \mathrm{~m}$ of the edge, a pattern that was significant for the Red-headed Woodpecker (bird scientific names, Table 1), American Robin, and Orchard Oriole $\left(\chi^{2} \geq 3.80\right.$, d.f. $\left.=1, P \leq 0.051\right)$ but not for Mourning Dove, Common Grackle, or Brown-headed Cowbird $\left(\chi^{2} \leq 1.84\right.$, d.f. $=1, P \geq 0.175$ ) (Table 1). Overall, these six species had $45 \%$ of their foraging within $20 \mathrm{~m}$ with all observations included and $49 \%$ without perch and feeder observations; when combined with the first seven, 56\% of foraging was within $20 \mathrm{~m}$ with perch and feeder observations included, and $61 \%$ without. Four of the 10 species that foraged throughout plots, generally foraged less than expected within $20 \mathrm{~m}$ of the edge, a pattern that was significant for the Eastern Kingbird, Red-winged Blackbird, and Baltimore Oriole $\left(\chi^{2} \geq 9.70\right.$, d.f. $\left.=1, P \leq 0.002\right)$ but not for the Blue Jay $\left(\chi^{2}=2.16\right.$, d.f. $\left.=1, P=0.142\right)$. These four species tended to forage farther out, with $30 \%$ of their foraging within $20 \mathrm{~m}$ regardless of perch and feeder use (Table 1). The Eastern Kingbird, Blue Jay, Baltimore Oriole, and Lark Sparrow, had the most foraging time in crop fields, each with $\geq 170$ observations (Table 1), followed by the Orchard Oriole, Red-headed Woodpecker, American Robin, and Red-winged Blackbird, each with $>100$ observations.

Two species, the Red-headed Woodpecker and Common Grackle, did not differ in their use of the five distance categories $\left(\chi^{2} \leq 7.99\right.$, d.f. $\left.=4, P \geq 0.092\right)$ nor in use of the area within $20 \mathrm{~m}$ of the edge versus beyond $\left(\chi^{2} \leq 0.402\right.$, d.f. $\left.=1, P \geq 0.526\right)$ when perches and feeders were included. The woodpecker commonly used perches, and the grackle, active feeders. When feeders and perches were not included, however, foraging patterns shifted, and $61 \%$ of the Red-headed Woodpecker's foraging was within $20 \mathrm{~m}$ of the edge $\left(x^{2}=6.26\right.$, d.f. $\left.=1, P=0.012\right)$, as was $50 \%$ of the Common Grackle's, but the latter remained not significant $\left(\chi^{2}=1.84\right.$, d.f. $\left.=1, P=0.175\right)$ (Table 1; Figure 2, ground use). Both of these species foraged on the ground, primarily within $20 \mathrm{~m}$ of the edge, but appeared to shift farther out when feeders and perches were available.

Distribution patterns of the Brown Thrasher, Lark Sparrow, American Robin, Orchard Oriole, Blue Jay, Eastern Kingbird, and Baltimore Oriole, differed among the five distance categories $\left(\chi^{2} \geq 14.1\right.$, d.f. $=4, P \leq 0.007$; perches and feeders included). The Brown Thrasher and Lark Sparrow typically foraged near the edge but, unlike the Lark Sparrow, the thrasher seldom went be- 
Table 1. Percentage of bird observations by species in crop fields within $20 \mathrm{~m}$ of a woody edge and (in parentheses) the number of observations per 100, 30-min periods at 12 study plots in east central Nebraska, 2005-2006

\begin{tabular}{|c|c|c|}
\hline Species & $\begin{array}{l}\text { Including perch and } \\
\text { feeder observations }\end{array}$ & $\begin{array}{l}\text { Excluding perch and } \\
\text { feeder observations }\end{array}$ \\
\hline \multicolumn{3}{|l|}{ Foraged primarily within $20 \mathrm{~m}$ of the edge } \\
\hline Eastern Bluebird (Sialia sialis) & $49 \%(57.6)^{* * *}$ & $100 \%(13.0)^{* * *}$ \\
\hline Brown Thrasher (Toxostoma rufum) & $90 \%(29.8)^{* * *}$ & $92 \%(27.0)^{* * *}$ \\
\hline Lark Sparrow (Chondestes grammacus) & $76 \%(170)^{* * *}$ & $69 \%(100)^{* * *}$ \\
\hline Song Sparrow (Melospiza melodia) & $50 \%(37.5)^{* *}$ & $100 \%(5.9)^{* *}$ \\
\hline Mean & $72 \%(348.8)$ & $79 \%(191.5)$ \\
\hline \multicolumn{3}{|c|}{ Foraged throughout plots but generally more than expected within $20 \mathrm{~m}$ of the edge } \\
\hline Mourning Dove (Zenaida macroura) & $50 \%(38.1)$ & $50 \%(38.1)$ \\
\hline Red-headed Woodpecker (Melanerpes erythrocephalus) & $37 \%(116.7)$ & $61 \%(33.7)^{* *}$ \\
\hline American Robin (Turdus migratorius) & $49 \%(106.9)^{*}$ & $49 \%(77.3)$ \\
\hline Common Grackle (Quiscalus quiscula) & $41 \%(82.2)$ & $50 \%(44.2)$ \\
\hline Eastern Kingbird (Tyrannus tyrannus) & $28 \%(273.8)^{* * *}$ & $29 \%(99.0)^{*}$ \\
\hline Blue Jay (Cyanocitta cristata) & $35 \%(212)$ & $30 \%(37.5)$ \\
\hline Red-winged Blackbird (Agelaius phoeniceus) & $25 \%(103.4)^{* *}$ & $25 \%(103.4)^{* *}$ \\
\hline Baltimore Oriole (Icterus galbula) & $30 \%(199.4)^{* *}$ & $49 \%(33.5)$ \\
\hline Mean & $30 \%(788.7)$ & $30 \%(273.4)$ \\
\hline
\end{tabular}

${ }^{*} P \leq 0.05 ;{ }^{* *} P \leq 0.01 ; * * * P \leq 0.001$

yond $10 \mathrm{~m}$ (Figure 2). Similarly, other species that foraged primarily near the edge, Eastern Bluebird, Gray Catbird, Song Sparrow, Northern Cardinal, and American Goldfinch, showed similar patterns, with some tending to remain close to the edge and others occasionally foraging farther, particularly when observations at perches and feeders were included (Table 1). The Lark Sparrow and Orchard Oriole were often observed in the area 10-20 m from the edge, often on perches or feeders; and the Blue Jay and Baltimore Oriole in the $30-40 \mathrm{~m}$ area, primarily on feeders (Figure 2). The American Robin tended to forage most within $10 \mathrm{~m}$ of the edge but also foraged regularly throughout study plots, mostly on the ground. The Eastern Kingbird foraged primarily beyond $10 \mathrm{~m}$ from the woody edge, frequently using perches.

Differences of least square means indicated a tendency for some species to travel farther into soybean fields than into corn fields (Table 2), but this difference was significant only for the American Robin $(F=4.81$; d.f. $=1 ; P=0.058)$, Brown-headed Cowbird $(F=1,208,693$; d.f. $=1 ; P=0.0006)$, and Orchard Oriole
$(F=248.25 ;$ d.f. $=1 ; P=0.040)$. These species traveled 12.8, 15.7, and $11.1 \mathrm{~m}$ farther into soybean fields than corn fields, respectively. While there was no significant effect of edge type on traveling distance, several species tended to travel somewhat farther into crop fields that had shelterbelts as a woody edge, and Eastern Kingbirds approached significance in this regard $(F=4.19$; d.f. $=1 ; P=0.069$, Table 2).

\section{Discussion}

Birds that forage for insects in crop fields benefit from a needed food resource and in turn help suppress pest insect populations (Jones et al., 2005). There are foraging constraints, however, including increased predation risk away from the edge and the energy costs of flight that must be balanced against food resources obtained for adults or young. These constraints may vary by species, habitat affinity, escape behavior, food availability, and other factors. In our study, all birds observed forag-

Table 2. Number of bird observations and distances traveled into crop fields (LS means) for species with $\geq 30$ observations, comparing type of crop (soybean, corn) and woody edge (riparian, shelterbelt)

\begin{tabular}{|c|c|c|c|c|c|c|c|}
\hline \multirow[t]{2}{*}{ Species } & \multirow{2}{*}{$\begin{array}{l}\text { No. of } \\
\text { Observations }\end{array}$} & \multicolumn{2}{|c|}{ Distance traveled $(\mathrm{m})^{\mathrm{a}}$} & \multirow[t]{2}{*}{$P$ value $^{\mathrm{a}}$} & \multicolumn{2}{|c|}{ Distance traveled $(\mathrm{m})^{\mathrm{a}}$} & \multirow[t]{2}{*}{$P$ value $^{a}$} \\
\hline & & Soybean & Corn & & Riparian & Shelterbelt & \\
\hline American Robin & 152 & $31.2(4.7)$ & $18.4(5.2)$ & 0.0576 & $22.3(5.0)$ & $27.2(4.7)$ & 0.3899 \\
\hline Baltimore Oriole & 194 & $33.9(4.9)$ & $17.9(6.4)$ & 0.0783 & $22.0(3.7)$ & $29.8(7.2)$ & 0.3638 \\
\hline Blue Jay & 209 & $26.0(3.3)$ & $26.3(3.8)$ & 0.9427 & $27.8(3.5)$ & $24.5(3.6)$ & 0.5358 \\
\hline Brown Thrasher & 33 & $15.8(4.7)$ & $10.6(5.1)$ & 0.3011 & $11.9(4.7)$ & $14.5(6.2)$ & 0.7119 \\
\hline Common Grackle & 79 & $31.9(2.5)$ & $22.8(4.2)$ & 0.1898 & $24.2(4.2)$ & $29.9(4.2)$ & 0.3659 \\
\hline Orchard Oriole ${ }^{b}$ & 48 & $29.1(5.0)$ & $18.0(5.1)$ & 0.0404 & $18.0(5.0)$ & Non-Est & - \\
\hline Red-headed Woodpecker ${ }^{b}$ & 41 & $26.8(11.3)$ & Non-Est & - & $25.3(19.3)$ & $28.4(19.3)$ & 0.9371 \\
\hline
\end{tabular}

${ }^{a}$ LS means, standard errors (in parentheses), and $P$ values were obtained using a repeated measures analysis of variance in SAS (SAS Institute Inc., 2000-2004).

${ }^{\mathrm{b}}$ LS means and $P$ values were non-estimable due to lack of observation data. 

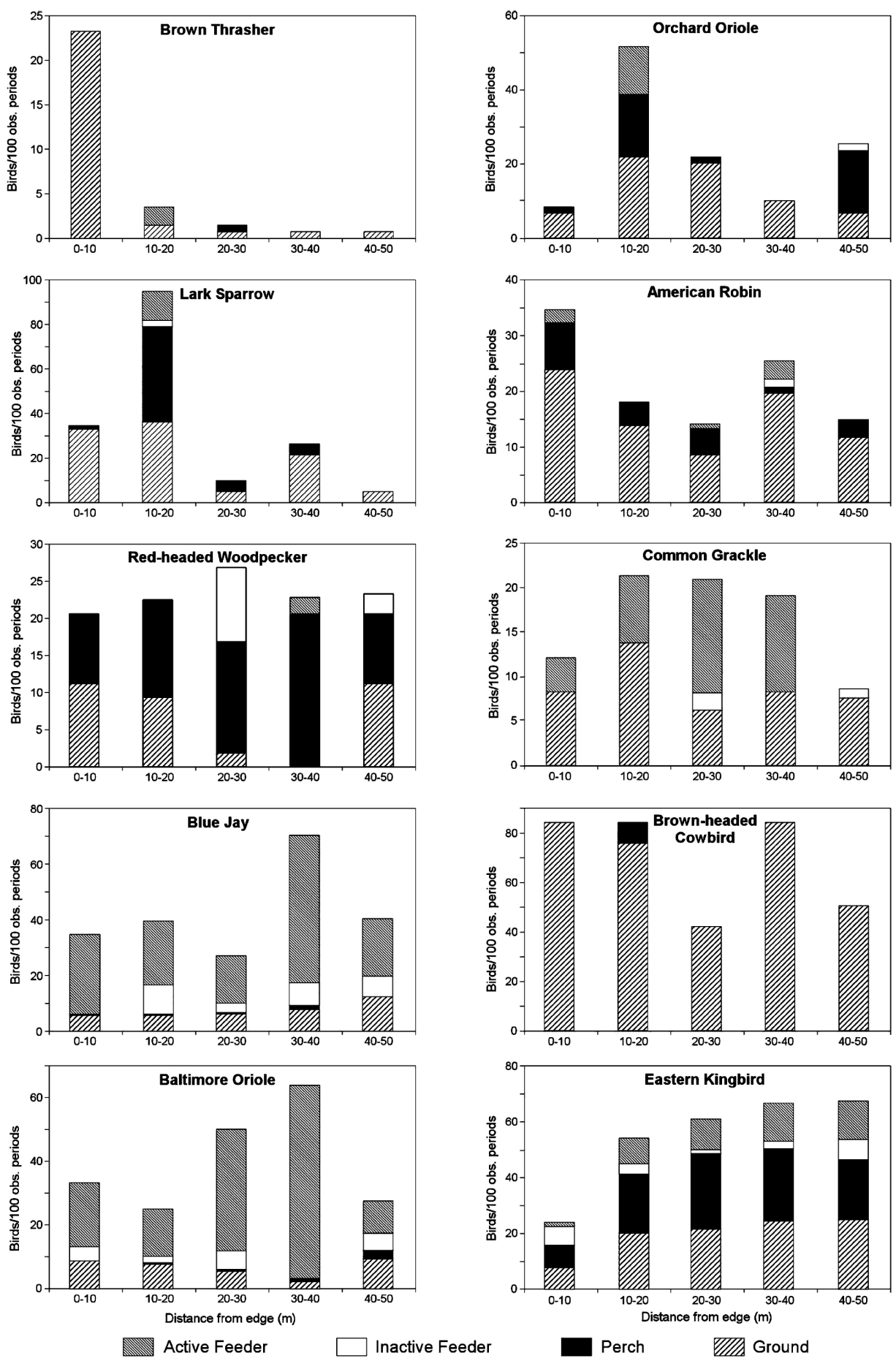

Figure 2. Birds per 100, 30-min observation periods (10 most common species) foraging in crop fields at five distance ranges outward from adjacent woody edges, 12 study plots, east central Nebraska, 2005-2006. Note that scales on vertical axes vary among species.

ing in the crop fields were woodland species that used the field edge near the trees, and a majority foraged most often within the $20 \mathrm{~m}$ adjacent to the protective woody cover. Even species that foraged most commonly beyond $20 \mathrm{~m}$ still had $30 \%$ of their use within $20 \mathrm{~m}$ of the field edge. Bird-friendly management within this $20 \mathrm{~m}$ functional edge such as reduced pesticide use or planting a grassy or herbaceous buffer (Henningsen and Best, 2005) could benefit a variety of birds and, at the same time, increase their impact on pest insects.

\subsection{Species response}

Bird species showed a range of field-edge use from those that remained near the edge to species that foraged throughout the plots and some that appeared to forage more at certain distances. The Brown Thrasher and Gray Catbird, for instance, are inconspicuous species that prefer to remain hidden, especially when they are disturbed (Cimprich and Moore, 1995; Cavitt and Haas, 2000). Other species, such as the Lark Sparrow, prefer to 
forage in low trees and shrubs as opposed to the open space in crop fields (Martin and Parrish, 2000). The Baltimore Oriole, Blue Jay, Red-winged Blackbird, Brown-headed Cowbird, Mourning Dove, Eastern Kingbird, Common Grackle, and American Robin foraged throughout the study plots and these species also have been observed foraging in crop fields up to $200 \mathrm{~m}$ from woody edges (Fitzmaurice, 1995; Sunderman, 1995).

The Eastern Kingbird commonly forages from perches for insects (Murphy, 1996) and, in our study, foraged primarily beyond $10 \mathrm{~m}$ from the woody edge, often from perches. Other species appeared to forage more often at 10-20 or 30-40 $\mathrm{m}$ from the edge. Such patterns may relate to species life history, food use versus availability at various distances, or other factors related to microclimate, wind, or turbulence (Brandle et al., 2004).

The Eastern Kingbird, Blue Jay, and Baltimore Oriole were the most commonly observed species with the greatest amount of foraging time in crop fields in our study. Along with the Redheaded Woodpecker, also commonly observed, these species foraged throughout the study plots and were observed most using feeders or perches. Their opportunistic use of feeders and perches throughout the plots suggests that these species might similarly respond to other food opportunities such as pest insect outbreaks in crop fields. Other species that typically foraged throughout plots or near the edge, even those that were less abundant, likely also contribute to the service of crop pest suppression. Jones et al. (2005), for example, included the Orchard Oriole, Brown Thrasher, and Eastern Bluebird in their list of functional insectivores in crop fields, adding credence to the concept that these species function to suppress crop insect pests.

Predators associated with edges may suppress crop pests by foraging within the crop field or, alternatively, by consuming pest insects blown to the edge by winds or attracted there for a life cycle need (Johnson et al., 1992). Furthermore, the calm air on the leeward side of woody habitats appears well suited for bats or birds to attack flying insects. It is likely that the combination of insectivores that forage on crop insect pests contribute in various ways, perhaps synergistically, to pest insect suppression, although effectiveness may vary depending on the insectivore's abundance, foraging location, and other factors.

\subsection{Pest suppression from edges}

Birds attracted to an active feeder or perch may forage opportunistically on the ground, so ground observations are not independent of the total use that included feeders and perches. Species that tended to remain near the edge or that foraged more often there also tended to forage farther when perch and feeder observations were included, indicating willingness to forage farther when food resources were available. Thus, farm fields that have food resources available for insectivorous birds, such as fields with some weeds present (Christensen et al., 1996; Beecher et al., 2002) or fields with herbaceous buffers (Henningsen and Best, 2005), are more likely to have birds foraging for insects, and potentially increased suppression of pest insect populations (e.g., Johnson et al., 1992; Kirk et al., 1996; Tremblay et al., 2001; Jones et al., 2005).

Producers who retain areas of non-crop habitat may benefit from the ecosystem service of pest insect suppression by birds foraging as functional insectivores (Jones et al., 2005) on their land. When adequate habitat is available, avian predators can reduce the impact of potential outbreaks of pest insects, such as European corn borers (Ostrinia nubilalis Hbn.), cutworms (Agrotis spp.), and weevils (Sphenophorus spp.) (Tremblay et al., 2001). This could reduce pest populations below the economic threshold that justifies pesticide application (Ehler, 2006), saving producers both money and labor.

\subsection{Management considerations}

Many studies have promoted the conservation of edge habitats in agroecosystems for birds and other wildlife (e.g., Johnson and Beck, 1988; Best et al., 1990), and some have argued for research on approaches that will best conserve wild nature while producing sufficient food (Green et al., 2005). Sotherton (1991) determined that field edges where pesticide applications were avoided or minimized had increased abundance and species richness of game birds, butterflies, and beneficial insects. Pesticide use reduces insect numbers and thus reduces food availability for insectivorous birds and the number of birds that forage in a field. Avoiding pesticide use in the $20 \mathrm{~m}$ functional edge would result in more foraging resources and might reduce harmful pesticide effects to predators without increasing economic losses to crop production (Dix et al., 1995). Crop yields within the functional edge are already low because of competition between crops and adjacent woody edges for water and nutrients (Brandle et al., 2004). Thus, producers can be less concerned about the possibility of reducing yields when managing functional edges to support birds and other wildlife that may in turn provide an ecosystem service of pest suppression.

Although there is concern regarding potential bird damage to crops in some locations, less than 10 of the 215 neotropical migrant birds are known to cause significant damage (Rodenhouse et al., 1995). Dolbeer (1990) estimated that crop field damage by Red-winged Blackbirds resulted in a loss of $<1 \%$ of crops in North America, but damage to individual crop fields can be high where fields are located near large bird roosts during late summer and fall when blackbirds flock and roost together. Redwinged blackbirds and others, however, commonly perch or roost directly on corn (Johnson and Caslick, 1982) or sunflower (Besser et al., 1979) plants. Shelterbelts or tree rows appear to have a minimal relationship to likelihood or impact of bird damage to crops (Johnson and Beck, 1988). Crop damage by foraging birds was not observed in this study.

Because woody habitats typically are linear with limited area, they usually are not sufficient for area-sensitive species, and the woody vegetation is avoided by grassland birds, many of which are in decline (Knopf, 1994; Grant et al., 2004; Brennan and Kuvlesky, 2005). Grassland species may occur where grassy habitat is available, such as in grassy strip cover (Henningsen and Best, 2005) or, more likely, where government-supported Conservation Reserve Program grasslands with larger areas and more square or rectangular shapes occur (Johnson and Schwartz, 1993). Linear woody habitats, however, support the highest avian species richness in agroecosystems (Best et al., 1995; Jones et al., 2005) and are often the primary non-crop habitat available in intensively farmed areas because they occur on non-tillable land or provide economic or other crop production benefits. Both woody and grassland habitats can contribute to bird conservation and pest insect suppression in agroecosystems but require planning in relation to overall goals, species of interest, habitat area, and landscape context (Henningsen and Best, 2005).

\section{Conclusion}

The results of this study indicate that the first $20 \mathrm{~m}$ of crop field adjacent to woody habitat is the functional edge where $\geq 56 \%$ of foraging occurred for 13 of the common species observed and $30 \%$ of foraging for the remaining four. Seven of the 13 species foraged primarily within $20 \mathrm{~m}$ of the edge, with $\geq 72 \%$ of their observations in this area. Non-crop field edges and associated birds can be used to foster a symbiotic relationship between birds and crop production. Reducing pesticide use or oth- 
erwise managing to benefit birds within this $20 \mathrm{~m}$ functional edge offers potential to enhance sustainability of both birds and crops in agricultural landscapes.

\section{Acknowledgments}

This study was funded through McIntyre-Stennis Forestry Research funds. Additional financial support was provided by the Center of Great Plains Studies; the Nebraska Statewide Arboretum; the Non-game and Endangered Species Fund, Wildlife Division, Nebraska Game and Parks Commission; and the University of Nebraska-Lincoln School of Natural Resources. The authors thank the anonymous reviewers for helpful comments on the manuscript; L.A. Powell for project advice; D. Porter, B. Bolander, and M. Cieslik for field assistance; D. Titterington for help acquiring research materials; J.E. Quinn, J.A. Goldenetz, and K.L. Baker for manuscript assistance; and the many private landowners for kindly allowing access to their property.

\section{References}

Beecher et al., $2002 ~ N$ N. A. Beecher, R. J. Johnson, J. R. Brandle, R. M. Case, and L. J. Young, Agroecology of birds in organic and nonorganic farmland, Conservation Biology 16 (2002), pp. 1620-1631.

Benton et al., 2002 T. G. Benton, D. M. Bryant, L. Cole, and H. Q. P. Crick, Linking agricultural practice to insect and bird populations: a historical study over three decades, Journal of Applied Ecology 39 (2002), pp. 673-687.

Besser et al., 1979 J. F. Besser, W. J. Berg, and C. E. Knittle, Late-summer feeding patterns of red-winged blackbirds in a sunflower-growing area of North Dakota, Proceedings of the 8th Bird Control 8 (1979), pp. 209-214.

Best et al., 1995 L. B. Best, K. E. Freemark, J. J. Dinsmore, and M. Camp, A review and synthesis of habitat use by breeding birds in agricultural landscapes of Iowa, American Midland Naturalist 134 (1995), pp. 1-29.

Best et al., 1990 L. B. Best, R. C. Whitmore, and G. M. Booth, Use of cornfields by birds during the breeding season: the importance of edge habitat, American Midland Naturalist 123 (1990), pp. 84-99.

Bianchi et al., 2006 F. J. J. A. Bianchi, C. J. H. Booij, and T. Tscharntke, Sustainable pest regulation in agricultural landscapes: a review on landscape composition, biodiversity and natural pest control, Proceedings of the Royal Society 273 (2006), pp. 1715-1727.

Brandle et al., 2004 J. R. Brandle, L. Hodges, and X. H. Zhou, Windbreaks in North American agricultural systems, Agroforestry Systems $6 \mathbf{1}$ (2004), pp. 65-78.

Brennan and Kuvlesky, $2005 \gg$ L. A. Brennan and W. P. Kuvlesky Jr., North American grassland birds: an unfolding conservation crisis?, Journal of Wildlife Management 69 (2005), pp. 1-13.

Cavitt and Haas, 2000 J. F. Cavitt and C. A. Haas, Brown Thrasher (Toxostoma rufum). In: A. Poole and F. Gill, Editors, The Birds of North America, The Birds of North America, Inc., Philadelphia, PA (2000) No. 557.

Christensen et al., 1996 K. D. Christensen, E. M. Jacobsen, and H. Nøhr, A comparative study of bird faunas in conventionally and organically farmed areas, Dansk Ornitologisk Forenings Tidsskrift 90 (1996), pp. 21-28.

Cimprich and Moore, 1995 D. A. Cimprich and F. R. Moore, Gray Catbird (Dumetella carolinensis). In: A. Poole and F. Gill, Editors, The Birds of North America, The Academy of Natural Sciences, and the American Ornithologists' Union, Philadelphia, PA, Washington, DC (1995) No. 167.

Dix et al., 1995 M. E. Dix, R. J. Johnson, M. O. Harrell, R. M. Case, R. J. Wright, L. Hodges, J. R. Brandle, M. M. Schoeneberger, N. J. Sunderman, R. L. Fitzmaurice, L. J. Young, and K. G. Hubbard, Influences of trees on abundance of natural enemies of insect pests: a review, Agroforestry Systems 29 (1995), pp. 303-311.

Dolbeer, $1990 \triangleright$ R. A. Dolbeer, Ornithology and integrated pest management: Red-winged Blackbirds Agelaius phoeniceus and corn, Ibis 132 (1990), pp. 309-322.

Ehler, 2006 L. E. Ehler, Integrated pest management (IPM): definition, historical development and implementation, and the other IPM, Pest Management Science 62 (2006), pp. 787-789.
Fitzmaurice, 1995 Fitzmaurice, R. L., 1995. Avian use of riparian corridors and adjacent cropland in east-central Nebraska. Master's Thesis. University of Nebraska, Lincoln, Nebraska.

Grant et al., 2004 T. A. Grant, E. Madden, and G. B. Berkey, Tree and shrub invasion in northern mixed-grass prairie: implications for breeding grassland birds, Wildlife Society Bulletin 32 (2004), pp. 807-818.

Green et al., 2005 R. E. Green, S. J. Cornell, J. P. W. Scharlemann, and A. Balmford, Farming and the fate of wild nature, Science 307 (2005), pp. 550-555.

Henningsen and Best, 2005 J. C. Henningsen and L. B. Best, Grassland bird use of riparian filter strips in southeast Iowa, Journal of Wildlife Management 69 (2005), pp. 198-210.

Johnson and Schwartz, 1993 D. H. Johnson and M. D. Schwartz, The Conservation Reserve Program: habitat for grassland birds, Great Plains Research 3 (1993), pp. 273-295.

Johnson and Beck, $1988 \rightarrow$ R. J. Johnson and M. M. Beck, Influences of shelterbelts on wildlife management and biology, Agriculture, Ecosystems, and Environment 22/23 (1988), pp. 301-335.

Johnson and Caslick, 1982 R. J. Johnson and J. W. Caslick, Habitat relationships of roosting and flocking red-winged blackbirds, Journal of Wildlife Management 46 (1982), pp. 1071-1077.

Johnson et al., 1992 R. J. Johnson, J. R. Brandle, R. L. Fitzmaurice, and K. L. Poague, Vertebrates for biological control of insects in agroforestry systems. In: J. A. Walla and M. Dix, Editors, Biological Control of Forest Pests in the Great Plains: Status and Needs - a Symposium. Proceedings of the 44th Annual Meeting: Great Plains Agricultural Council Forestry Committee (1992), pp. 77-84 Publication No. 145.

Jones et al., 2005 - G. A. Jones, K. E. Sieving, and S. K. Jacobson, Avian diversity and functional insectivory on north-central Florida farmlands, Conservation Biology 19 (2005), pp. 1234-1245.

Kirk et al., 1996 D. A. Kirk, M. D. Evenden, and P. Mineau, Past and current attempts to evaluate the role of birds as predators of insect pests in temperate agriculture, Current Ornithology 13 (1996), pp. 175-269.

Knopf, 1994 F. L. Knopf, Avian assemblages on altered grasslands, Studies in Avian Biology 15 (1994), pp. 247-257.

Martin and Parrish, 2000 J. W. Martin and J. R. Parrish, Lark Sparrow (Chondestes grammacus). In: A. Poole and F. Gill, Editors, The Birds of North America, The Birds of North America, Inc., Philadelphia, PA (2000) No. 488.

Murphy, 1996 M. T. Murphy, Eastern Kingbird (Tyrannus tyrannus). In: A. Poole and F. Gill, Editors, The Birds of North America, The Birds of North America, Inc., Philadelphia, PA (1996) No. 253.

Perkins et al., 2003 M. W. Perkins, R. J. Johnson, and E. E. Blankenship, Response of riparian avifauna to percentage and pattern of woody cover in an agricultural landscape, Wildlife Society Bulletin 31 (2003), pp. 642-660.

Robbins, 1981 C. S. Robbins, Effect of time of day on bird activity, Studies in Avian Biology 6 (1981), pp. 256-275.

Rodenhouse et al., 1995 N. L. Rodenhouse, L. B. Best, R. J. O'Connor, and E. K. Bollinger, Effects of agricultural practices and farmland structures. In: T. E. Martin and D. M. Finch, Editors, Ecology and Management of Neotropical Migratory Birds: A Synthesis and Review of Critical Issues, Oxford University Press, NY (1995), pp. 269-293.

SAS Institute Inc., 2000-2004 $>$ SAS Institute Inc., SAS 9. 1. 3 Help and Documentation, SAS Institute Inc., Cary, NC (2000-2004).

Sorensen, $1948-\mathrm{T}$. Sorensen, A method of establishing groups of equal amplitude in plant sociology based on similarity of species content and its application to analyses of the vegetation on Danish commons, Det Kongelige Danske Videnskabernes Selskab Bioogiske Skrifter 5 (1948), pp. $1-34$.

Sotherton, 1991 N. W. Sotherton, Conservations headlands: a practical combination of intensive cereal farming and conservation. In: L. G. Firbank, N. Carter, J. F. Darbyshire and G. R. Potts, Editors, The Ecology of Temperate Cereal Fields, Blackwell Scientific Publications, Oxford, United Kingdom (1991), pp. 373-397.

Sunderman, 1995 Sunderman, N. J., 1995. Avian use of field windbreaks, herbaceous fencerows, and associated cropfields in east-central Nebraska. Master's Thesis. University of Nebraska, Lincoln, Nebraska.

Tremblay et al., 2001 A. Tremblay, P. Mineau, and R. K. Stewart, Effects of bird predation on some pest insect populations in corn, Agriculture, Ecosystems, and Environment 83 (2001), pp. 143-152.

Tsitsilas et al., 2006 A. Tsitsilas, S. Stuckey, A. A. Hoffmann, A. R. Weeks, and L. J. Thomson, Shelterbelts in agricultural landscapes suppress invertebrate pests, Australian Journal of Experimental Agriculture 46 (2006), pp. 1379-1388. 